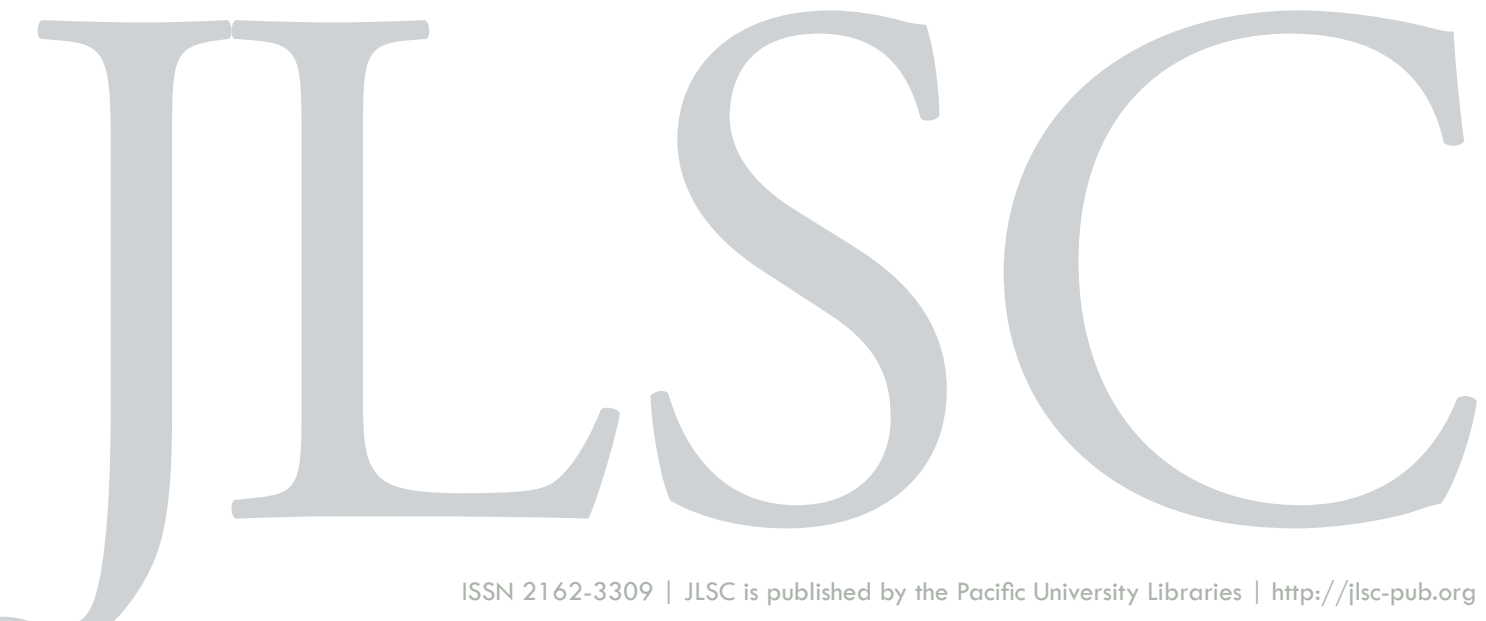

Volume 8, General Issue (2020)

\title{
"You Need to Make it as Easy as Possible for Me": Creating Scholarly Communication Reports for Liaison Librarians
}

\author{
Jessica Lange \& Carrie Hanson
}

Lange, J. \& Hanson, C. (2020). "You Need to Make it as Easy as Possible for Me": Creating Scholarly Communication Reports for Liaison Librarians. Journal of Librarianship and Scholarly Communication, 8(General Issue), eP2329. https://doi.org/10.7710/2162-3309.2309

This article underwent fully anonymous peer review in accordance with JLSC's peer review policy. 


\title{
"You Need to Make it as Easy as Possible for Me": Creating Scholarly Communication Reports for Liaison Librarians
}

\author{
Jessica Lange \\ Scholarly Communications Librarian, McGill University \\ Carrie Hanson \\ Skills Development Officer, McGill University
}

INTRODUCTION The typical trifecta of liaison librarian positions (collections, reference, and teaching) is shifting to include additional skillsets and competencies, particularly scholarly communications. While liaison librarians adapt to these changing roles, the question of how to upskill and train liaison librarians in scholarly communications is timely and still in flux. The lack of time required to improve these competencies and skills is an oft-cited challenge. DESCRIPTION OF PROJECT To address the challenge of lack of time, this article describes a pilot project undertaken with the aid of a Master of Information Studies practicum student to create scholarly communications reports for liaison librarians. These reports provide background knowledge and discipline-specific information about the scholarly communications landscape, particularly within the institutional context. The goal of the reports is to provide liaison librarians with greater contextual knowledge of their disciplines and the publishing patterns within their departments. This article will discuss the methodology behind creating these reports as well as feedback from liaison librarians on their relevance and potential use. NEXT STEPS The initial pilot was promising, however using a practicum student to create such reports may not be sustainable. Other possibilities include holding "research report retreats" for liaison librarians to complete their own reports with a scholarly communications expert on hand. Additionally, institutions without a master's program in library and information studies could consider the creation and updating of such reports as a backup project for existing fulltime or student staff.

Received: 07/16/2019 Accepted: 02/16/2020

Correspondence: Jessica Lange, 550 Sherbrooke West, West Tower, 6th floor, suite 680, Montreal, Quebec H3A 1B9, jessica.lange@mcgill.ca

(C) 2020 Lange \& Hanson. This open access article is distributed under a Creative Commons Attribution 4.0 License (https://creativecommons.org/licenses/by/4.0/) 


\section{INTRODUCTION}

Scholarly communications (SC) is becoming a core function of liaison librarians' work. As noted in Bonn's (2014) article " $[\mathrm{w}] \mathrm{e}$ are seeing a heightened expectation that librarians who support disciplinary scholarship are fluent in the language of scholarly communication and can address its opportunities and challenges. Scholarly communication literacy has become a core competency for academic librarians" (emphasis added) (p. 132). This is part of a greater trend within liaison librarianship. The typical trifecta of liaison librarian positions (collections, reference, and teaching) is evolving, and the role now demands greater integration into the research life cycle at the university. Scholarly communications is a notable example of an area where liaison librarians can expand their capabilities to assist students and researchers. While liaison librarians adapt to these changing roles, the question of how to best upskill liaison librarians in SC is timely and still in flux. Although much of the literature focuses on training as a means to develop SC competencies, training is often one-shot and not specifically tailored for disciplinary differences. To fill the gap between what general training sessions can provide and what is specifically happening in a particular department, the McGill Library launched a pilot program to create scholarly communication reports for liaison librarians. These reports provided department-specific information about faculty publishing patterns, open access uptake among faculty members, as well as the disciplinary publishing culture. As Malenfant (2010) noted in her article about integrating scholarly communication competencies into liaison work, "[i]n every department there's a different hook, a different key...You have to find specific examples from their societies, their journals, and point out prohibitive language in agreements they actually would be signing" (p. 68). These reports would provide that "hook" or "key" to the departments, allowing liaison librarians to demonstrate superior understanding of the scholarly communications landscape in their departments and integrate themselves more fully into research discussions. Furthermore, these reports would respond to one liaison librarian's dictum in Malenfant's (2010) article that "since you're expecting me to do a new thing [scholarly communications], you need to make it as easy as possible for me” (pp. 67-68).

\section{LITERATURE REVIEW}

\section{Changing Roles of Liaison Librarians}

The integration of scholarly communications into liaison librarian roles saw greater discussion starting in mid-2000s when many libraries launched their institutional repositories (IR). Articles from this era focus on how libraries could leverage liaison librarians to promote these repositories (Bailey, 2005; Beaubien, Masselink, \& Tyron, 2009; Jenkins, Breakstone, \& Hixon, 2005; Philips, Carr, \& Teal, 2005; Walters, 2007). These articles describe how and why liaison librarians (sometimes also referred to as subject specialists or reference librarians) are ideally 
suited for promoting IRs. The articles reflect on the natural extension of subject librarians' familiarity with "the general academic milieu and the cultures of different disciplines" and how libraries could harness this knowledge in repository promotion (Jenkins et al., 2005, p. 315). Over time, the literature developed beyond describing liaison librarians as simply promoters of IRs to liaison librarians becoming more active and embedded participants in the research process. Several articles and reports discussed this changing role of liaison librarians (Auckland, 2012; Gabridge, 2009; Kenney, 2014; Ippolitti, 2017; Jaguszewski \& Williams, 2013; Malenfant, 2010; Miller \& Presley, 2015; Rodwell \& Fairbarin, 2008; Turtle \& Courtois, 2007). The 2015 Association of Research Libraries (ARL) SPEC Kit Evolution of library liaisons noted several areas that were emerging as part of the liaison portfolio, the top three among them: assistance with scholarly impact and metrics, promotion of the institutional repository, and consultation on open access issues (Miller \& Presley, 2015). Going further, Bruns, Brantley, and Duffin (2015) declared that, "researchers will be better served if scholarly communications is considered a core competency of subject librarians, similar to reference, instruction, and collection development" (p. 138). Given the literature presented, it is not surprising that the integration of SC topics into liaison librarian roles has advanced to the extent that liaison job postings often require scholarly communications competencies (Finlay, Tsou, \& Sugimoto, 2015; Malenfant, 2010; Mears \& Bandy, 2017).

\section{Challenges}

As liaison librarian positions continue to evolve, librarians and library administrators are exploring how to best prepare liaison librarians to integrate scholarly communications into their work and develop core competencies in this area. Common challenges cited in the literature include faculty perceptions of librarians' roles, lack of confidence, as well as concerns about ever-expanding responsibilities (e.g. jack-of-all-trades, master of none) (Beaubien et al., 2009; Bruns et al., 2015; Vine, 2018).

Faculty perceptions of librarians as primarily "content buyers" makes it difficult for liaison librarians to sell their new skills to faculty (Burpee and Fernandez, 2014; Vine, 2018). In their interviews with librarians with SC responsibilities at Canadian academic institutions, Burpee and Fernandez (2014) noted some respondents reported that, "the library was seen as a service support unit for the institution rather than an academic partner in the research enterprise" ( $p$. $10)$. Because faculty do not see librarians as the primary support people for SC questions Bruns et al. (2017) argued that librarians are therefore not likely to prioritize the development of these areas. Mullen's (2011) article examining open access and how it connects to liaison librarian roles also discussed the issue of prioritization. Mullen (2011) stated that liaison librarians might not feel "that 'scholarly communication' or 'open access' has much relevance to their busy roles in the library" (p. 8). Disconnect over priorities was also an issue at the ARL Library Liaison In- 
stitute. Bakkalbasi, Rockenbach, Tancheva, and Vine (2016) remarked that, "[w]hile scholarly communication issues surfaced at the [ARL Library Liaison] Institute, they did not rise to the top of the list for most liaison librarians. We have identified this as a possible area of disconnect between institutional goals and individual liaison goals" (p. 121).

Another commonly-identified challenge in the literature is anxiety and a lack of confidence in learning the new skills required to be fluent in SC issues. Vine (2018) agreed that for liaison librarians connecting with researchers on SC issues could be "daunting" (p. 422). Anxiety and a lack of confidence in assisting researchers in SC topics is also reflected in Burpee and Fernandez (2014), Bruns et al. (2017), Ippoliti (2017), and Wirth and Chadwell (2010). As Beaubien et al. (2009) found during the discussion period of a workshop series to familiarize liaison librarians with SC topics, "there emerged a natural apprehension that the project would lead to increased workload and an insecurity about confidently representing the interests of the library to the rest of the university community" (p. 101). During the integration of SC roles at University of Minnesota Libraries, Malenfant (2010) remarked, that amongst the liaison librarians, there was a "continuing lack of confidence" (p. 67).

Lack of confidence is often coupled with the subject of time, both in terms of the time to upskill but also the time to take on additional tasks. Feelings of trying to balance expanding workloads are mentioned in the SPEC Kit, Evolution of library liaisons (Miller \& Presley, 2015) and appear in several articles relating to changing liaison librarian roles and SC competencies. For example, one interviewee in Burpee and Fernandez's (2014) study said, "[ $t]$ he real issue for us is time. The liaison librarian is such a busy role...If I could give my librarians anything it would be more time" (p. 10). Malenfant (2010) also noted the liaison librarians felt like they have to "take everything on" (p. 71) and Mears and Bandy (2017) reflected, "adding duties to reference and instruction librarian responsibilities is often seen as the solution, but this may not be viable in the long term because the scholarly communications landscape has significantly expanded." (p. 148). Vine (2018), Ippoliti (2017), and Kenny (2014) also mentioned lack of time and the difficulty liaison librarians face in appropriately prioritizing and managing their workloads.

To address these challenges (lack of confidence, lack of time, and faculty perceptions), the literature discusses three primary approaches: developing training opportunities, creating sets of $\mathrm{SC}$ resources, and completing environmental scans.

\section{Upskilling}

Workshops and Training

One of the primary methods for introducing liaison librarians to scholarly communications 
is holding workshops or training sessions, and training is continually advocated for in the literature (Bakkalbasi et al., 2016; Vine, 2018;). The Association of College and Research Libraries (ACRL) Scholarly Communications Roadshow is one example, but the literature outlines initiatives developed internally at libraries as well. The depth and length of the training varies. Some libraries undertook more in-depth training, including several workshops on various topics for librarians (Ippoliti, 2017; Tierney \& Kuyper-Rushing, 2016). Beaubien et al, (2009) described their Scholarly Communication Education Program; a four-part series of workshops to introduce topics related to the repository and other scholarly communications issues around author rights. Rodriguez (2015) also discussed a training program at Oakland University, where they held several training opportunities on open access topics in preparation for Open Access Week and the launch of the institutional repository. Other articles described single workshops such as Wirth and Chadwell (2010) and Bruns et al. (2015) which both discussed author rights workshops held at their institutions. Hurrell and Murphy (2019) similarly outlined a one-time training program for front-line staff to improve scholarly communication competencies.

Libraries sometimes combine training efforts with other approaches to create a greater support structure. For example, Sewell and Kingsley (2017) described a training program held at Cambridge University on SC topics, although their training took an additional approach of locating interested librarians within their organization who wanted to become "ambassadors" and take a more active role in scholarly communications on campus. These ambassadors then became point people within the library on these topics and led training efforts. Kirchner (2009) also positioned training as one component in a multi-pronged approach at the University of British Columbia, where in addition to a training program, librarians completed an environmental scan of their areas and some librarians participated in an ARL research project on changes in scholarship models.

Some institutions also distribute surveys to liaison librarians to gauge their knowledge and comfort of SC topics (Bresnahan \& Johnson, 2013; Klain-Gabbay \& Shoham, 2016; Malone \& Burke, 2016). These institutions then used the survey results to identify further training opportunities.

\section{Toolkits, Resource Lists, and Guides}

As described above, training is one of the primary means of upskilling, but training should be part of a continual learning effort. As noted in Kirchner's (2009) article on integrating SC responsibilities into liaison librarian work at the University of British Columbia, although the training period and work by the Steering Committee fostered a sense of enthusiasm and interest in SC topics, they noted a drop-off in engagement after the initial, 
concerted push. One approach for engaging liaison librarians beyond training workshops is the development of toolkits or sets of resources (Bruns et al., 2015). These resources could include lists of professional development resources and other opportunities for self-directed learning that go beyond a single instruction session (Cohen, 2017).

\section{Environmental Scans}

Another method for developing scholarly communications competencies for liaison librarians is completing environmental scans. Environmental scans can take different forms, but a resource that is often referred to is the "Faculty Activism in Scholarly Communications: Opportunity Assessment Instrument” (Van Orsdel, 2007). This document includes several checklist items such as how many faculty serve on editorial boards, which grant funding agencies have open access requirements, whether or not faculty members have published in OA journals, and locating disciplinary repositories in the field. Bruns et al. (2015) described having liaison librarians complete environment scans of their faculty/department as one part of a three-pronged approach to create "scholarly communication coaches" at their library. The environmental scan included reviewing major journals and repositories for their discipline, investigating the discipline's scholarly societies and associations' positions on open access, as well as reviewing faculty deposits in the institutional repository. In addition to completing these environmental scans, liaison librarians also attended a workshop on author rights and had a toolkit of resources available for their use. Kirchner (2009) and Malenfant (2010) also described environmental scan approaches taken at their institutions. As demonstrated in the review of the literature, there are many approaches to upskill liaison librarians in scholarly communications. Training is the primary method but has several drawbacks: it is often one-shot, not necessarily discipline-specific, nor immediately relevant to a liaison's individual context. Furthermore, training does not address the third challenge outlined in the literature: lack of time and workload balance. To overcome these two challenges, the Scholarly Communications Librarian at McGill University developed a pilot project to create scholarly communication reports (similar to environmental scans) for two liaison librarians. A practicum student from the McGill University Master of Information Studies program created and developed the reports, which was mutually beneficial. Firstly, the liaison would receive a tailored report about the scholarly communication practices of their faculty, thus alleviating them of the time to create such a report themselves. Secondly, the practicum student would receive deeper training in scholarly communications issues.

\section{CONTEXT}

McGill University is a large research-intensive university based in Montreal, Canada, with a population of over 40,000 undergraduate and graduate students. The McGill Library operates 
on a combined liaison/functional specialist model. The Library employs over 30 liaison librarians who act as direct connections to various departments, schools, and faculties on campus. Their roles include the traditional model of reference, collections development, and instruction. However, like trends in other academic libraries, their roles have been expanding into areas such as digital humanities, research data management, and scholarly communications, among others. These additional areas are not specifically included in job descriptions for liaison librarians at this institution. As such, the development of SC competencies, for example, is largely at the individual liaisons' discretion.

The Library has employed several functional specialists in areas such as copyright, scholarly communications, data, and user experience. These positions act as "super liaisons," who work across all disciplines and act as resources on these topics to other library staff and librarians. Similar to the articles described in the literature review, McGill Library has undertaken several initiatives to improve scholarly communications competencies. These initiatives have included distributing a needs analysis survey, offering workshops and training on author rights, as well as creating a toolkit on the McGill Library intranet with relevant resources for engaging in scholarly communications (e.g., sample email templates to solicit deposits for the repository). There also exists a Scholarly Communications Standing Committee and the Scholarly Communications Librarian frequently blogs, on the library's intranet, about major changes in the scholarly communications landscape.

\section{DESCRIPTION OF THE PILOT PROJECT}

\section{Practicum}

The practicum program at McGill University is a one-semester course credit for second-year Master of Information Studies students. The practicum provides students with the opportunity to obtain course credit while also gaining practical experience. The practicums include one hundred hours of work over twelve weeks and are unpaid.

In Fall 2018, the Scholarly Communications Librarian submitted a practicum proposal to the School of Information Studies. The posting included the following description:

The practicum student will assemble a scholarly communications report specific to two disciplines at McGill University (one from a sub discipline within the humanities and social sciences, and one from a sub discipline within the physical sciences, life sciences, and engineering). 
This is a pilot project for the Library to determine the relevance and usefulness of these types of reports to liaison librarians. As such, in addition to creating the reports, the practicum student may conduct a brief evaluation at the end of the project.

Once the Scholarly Communications Librarian selected the practicum student, the first two weeks of the practicum involved the student reviewing SC topics and literature in order to obtain a basic understanding of key terms and concepts such as open access, self-archiving, ORCiDs, grant-agency open access policies, etc. Although courses in the Master of Information Studies program cover SC topics to some extent, there is no dedicated course on scholarly communications issues. As such, a review of these issues was necessary in order for the student to complete the project successfully.

Once the student obtained the necessary background information, they were required to interview both of the liaison librarians selected for this project. The student used these interviews to assess the specific user needs of the liaison librarians: which scholarly communications topics did they want to know more about for their department? Which specific challenges did they hope these reports would address? The student designed the interview questions themselves and took notes during the interviews for analysis afterwards. While the liaison librarians had similar information needs overall, two specific information requests came out of the interviews: the social sciences liaison would like additional information about journals' data deposit policies and the science liaison wanted information on cross-institutional collaboration between their department and external organizations. The student added this information to the reports for the liaison librarian in question.

The student spent the remainder of the practicum researching and compiling the reports, as well as documenting their research methodology.

\section{Composition of the Reports and Report Methodology}

The practicum student structured the reports based on the interviews with the liaison librarians as well as an in-house template that the Scholarly Communications Committee developed called the "Scholarly Communications Opportunity Assessment Instrument." The Committee modeled this template off Van Orsdel (2007). Using this assessment instrument alongside feedback from the interviews, the student and Scholarly Communications Librarian reviewed the potential topics within the timeframe of the project, and decided which topics the reports would include. 
A sample table of contents is included below:

\section{Contents}

Scholarly communication in the field

- Definitions: Green, gold, and hybrid open access

- Top journals for McGill University political science professors, based on publication patterns

Top publishers of these journals

- Article processing charges

- Embargos

- Grant agency open access policy compatibility

- Copyright policies

McGill University political science professor publishing habits

- McGill University political science professors publishing in gold OA journals

- Percentage of articles published by McGill University political science professors in hybrid journals which were made open access

- McGill University professors who paid an article processing change (APC) in a hybrid journal to publish open access

Other McGill University political science publishing patterns

- Former political science professors publication patterns

- McGill University political science graduate students' publication patterns

Appendix A: Political science journals, APC table

Appendix B: Political science journals, APC graph

Appendix C: Political science journals embargo lengths

Appendix D: Grant agency compatible political science journals

Appendix E: Grant agency incompatible political science journals

Appendix F: Political science journals licensing and copyright policies 
Table 1 provides an example of a table featured in one of the reports.

\begin{tabular}{lll} 
Journal & Publisher & Journal Type \\
\hline Acta Politica & Palgrave & Hybrid \\
\hline American Political Science Review & Cambridge & Hybrid \\
\hline British Journal of Political Science & Cambridge & Hybrid \\
\hline Canadian Journal of Political Science & Cambridge & Hybrid \\
\hline Canadian Political Science Review & Independent & Open Access \\
\hline Comparative Political Studies & SAGE & Hybrid \\
\hline Cooperation and Conflict & SAGE & Hybrid \\
\hline Electoral Studies & Elsevier & Hybrid \\
\hline Études Internationales & Université Laval & Hybrid \\
\hline French Politics & Palgrave & Hybrid \\
\hline International Organization & Cambridge & No OA option \\
\hline International Studies Quarterly & Oxford & Hybrid \\
\hline Journal of Elections, Public Opinion and Parties & Taylor and Francis & Hybrid \\
\hline Nations and Nationalism & Wiley & Hybrid \\
\hline Political Communication & Taylor and Francis & Hybrid \\
\hline Political Research Quarterly & SAGE & Hybrid \\
\hline Political Studies & SAGE & Hybrid \\
\hline Political Theory & SAGE & Hybrid \\
\hline Problems of Post-Communism & Taylor and Francis & Hybrid \\
\hline PS - Political Science and Politics & Cambridge & Hybrid \\
\hline Review of International Political Economy & Taylor and Francis & Hybrid \\
\hline & &
\end{tabular}

Table 1. Top 21 Journals for McGill University political science professors, based on publishing patterns

The student developed the report methodology in consultation with the Scholarly Communications Librarian. The student retrieved the data from several sources:

- Scopus and Web of Science databases (faculty publishing patterns)

- SHERPA/RoMEO (journal policies)

- Directory of Open Access Journals (DOAJ) (gold open access journals)

- Publisher websites (APCs, hybrid options)

- SciVal (cross-institutional collaboration)

- McGill University departmental webpages (names of faculty members) 


\section{ASSESSMENT}

Following the creation of the two reports, the liaison librarians had one month to review the reports after which the Scholarly Communications Librarian scheduled a 30-minute inperson interview. The Scholarly Communications Librarian sent the discussion questions to the liaison librarians in advance. The questions included:

1. Why did you choose to participate in this pilot project?

2. How well did the report meet your expectations? (on a scale of $1-5,1=\mathrm{did}$ not meet my expectations at all, 5=completely met all my expectation)

3. Would you describe the report as valuable to you in your role as a liaison librarian?

4. If yes, please elaborate.

5. Which components of the report were the most valuable?

6. Were there any components of the report that were not relevant/useful? If so, why?

7. If another report was to be made for you again in the future, do you have any suggestions for improvement?

8. Do you foresee this report being used in your work? If so, how? Describe any scenarios in which this report would be relevant/useful.

Additional questions or prompts for information occurred during the interview as questions or clarification naturally arose. The Scholarly Communications Librarian sent the interview notes afterwards to the liaison librarians in order to confirm that the summaries accurately reflected their comments. This also provided an opportunity for the liaison librarians to add any additional reflections.

The liaison librarians gave their consent for their comments to be included in this article. Formal ethics approval was not required as it fell within "Quality assurance and quality improvement studies, program evaluation activities, and performance reviews... management or improvement purposes," which do not require research ethics approval (Canadian Institutes of Health Research, Natural Sciences and Engineering Research Council of Canada, Social Sciences and Humanities Research Council, 2018, p. 18).

\section{Motivation to Participate}

The initial motivation for the two liaison librarians was slightly different. One liaison librarian had intuitions about the publishing patterns and open access culture in their area and wanted them confirmed. This liaison librarian also mentioned that they wanted to offer bet- 
ter service to faculty members and that the reports could help identify areas in which they could offer additional services. For example, this liaison librarian noted that from reading the report it "seems profs don't know much about green open access so there's more that could be done in that regard."

The other liaison librarian had prepared a touch table exhibit highlighting faculty research outputs and thought it would be timely to have the report. Overall, both liaison librarians agreed that the reports were valuable to their work and that the reports met their expectations (reported 3.5 and 4 respectively, with $1=$ not at all, $5=$ completely).

In reviewing the comments from the two interviews, several additional themes emerged:

\section{Graduate Students as a Target Audience}

Both liaison librarians mentioned that they saw the reports as particularly useful for targeting and reaching out to graduate students. They mentioned these reports could assist them in "better preparing graduate students who were entering the field" and help graduate students know what to consider when publishing.

\section{Interest/Surprise in APC Information}

Both liaison librarians found the information about APCs to be particularly relevant. One noted the APCs in their discipline were "shockingly high" while the other appreciated having this information readily available, as it is sometimes difficult to locate on publisher websites.

\section{Sharing}

Both thought there was potential to share the reports to a greater audience. One liaison librarian mentioned they could share the list of journals and the requirements for grant agency OA policies with researchers or new faculty, for example "we have these lists, this can be useful, especially if you're writing a grant and you need to account for these APCs." Both mentioned that the reports contained information that could be shared at a departmental meeting, with one specifying further that it could be used to discuss national granting agencies' open access requirements.

Finally, one liaison librarian remarked on the usefulness of the information on data sharing policies of journals as they were expanding their knowledge in that area. This liaison librarian further commented on the timeliness of the report, as a data policy from the national 
funding agencies was on the horizon and this could be a "good time to remind them [faculty members] of the regular OA requirements since they're complementary."

\section{Suggestions for Improvement}

Both liaison librarians had suggestions for future improvement, particularly information they would like to have seen included in the reports:

- List of professors who had received a grant from a national funding agency that had an open access policy

- List of journals that require ORCiDs

- Raw data used to compile the report

- Clearer methodology (e.g. including information on whether name disambiguation was undertaken)

- List of professors who had deposited in McGill Library's institutional repository

- An analysis of open access in their department before and after the introduction of open access mandates for Canada's national funding agencies.

- List of countries (rather than regions) for collaborating institutions

\section{Challenges: Lack of Time and Faculty Awareness}

Earlier in the paper, the literature highlighted that lack of time was a reason why liaison librarians do not always engage in scholarly communications activities. In their interviews, one liaison librarian directly stated that they wanted to participate in this pilot project because they did not have a lot of time and they planned to do similar reports for their other disciplines in the future. By having this first report created for them, they received a "good push in that direction." This liaison librarian later went on to state that they "would love to do a report like this and also add researcher portraits ... it would be something to share with faculty if they were interested." One of the liaison librarians also addressed another challenge mentioned earlier: that faculty do not see the library as having expertise in scholarly communications areas. They mentioned that the SC report is "also a way to integrate myself with their [the faculty member's] work...they [faculty] can think of the library when they have questions like that [related to open access and SC], which they don't do right now but that's not surprising."

\section{NEXT STEPS}

The initial pilot was promising, and the liaison librarian interviews demonstrated the value 
and relevance of creating such reports. Additionally, follow-up with the practicum student confirmed that the project had provided the student with deeper scholarly communications training. The student remarked:

Before completing the practicum, I had basic knowledge of the open access movement. I was only vaguely aware of terms like gold OA, article processing charges, and embargos. However, by the end of the practicum, I could explain and discuss each term at length. I feel I could comfortably explore any of these topics in a variety of academic fields.... While I did not pursue a scholarly communications librarian position following graduation, I work in a university setting with academic faculty and staff, and I feel comfortable speaking with librarians and faculty on this topic. While I am still by no means an expert in the topic, I feel I can be an advocate for open access in my university.

Beyond the scholarly communications training, the student noted the practicum was valuable for learning how to sift through and synthesize large amounts of information and data. With only two liaison librarians included in the original pilot, there is only preliminary information as to whether the reports sufficiently helped to overcome some of the challenges outlined earlier in the paper: lack of time and workload balance, lack of confidence, and faculty awareness of SC services.

Although one liaison librarian directly referenced lack of time and their desire to increase faculty awareness of the library, neither liaison librarian expressed that a lack of confidence in SC topics was their motivation for participating in the pilot project. This could be a self-selection bias, in that liaison librarians who were already comfortable and fluent in SC topics were the ones to put their names forward. For example, one liaison librarian stated that their initial inclination to join the pilot was to confirm if their impressions about their faculty were correct, and both demonstrated fluency with SC topics in the interviews. It seemed to the Scholarly Communications Librarian that the reports served to fill the last gap in their SC knowledge, facilitating easy access to information they could share with faculty. There are still demonstrated benefits to creating the reports (as discussed in the liaison librarian interviews) but at this moment, it is unclear if creating reports on behalf of liaison librarians would alleviate anxiety and lack of confidence around these issues.

In spite of the initial, encouraging results, the Scholarly Communications Librarian has not decided whether the pilot will continue. Although using a practicum student to run the pilot and compile the reports was successful and beneficial to both the institution and student in the short term, relying on a practicum position to continue this work is neither sustainable nor ethical, as it relies upon temporary, unpaid labor. Even without these con- 
siderations, practicums only occur once a year during the winter semester. This schedule means that a student could only produce two reports a year using this method. That stated, now that a methodology and template already exists, the Scholarly Communications Librarian might explore other opportunities to collaborate with liaison librarians to work on these reports together. For example, they could experiment with holding "research report retreats" whereby the Scholarly Communications Librarian organizes a time for the liaison librarians to work on creating the reports together, having the Scholarly Communications Librarian present in the room to assist with any questions.

The authors are also aware that most institutions will not have access to students in a master's program in library and information studies. In such cases, institutions could explore the creation of SC reports by using existing staff members or student workers from any disciplinary background who have an interest in and aptitude for scholarly communications topics. The practicum student herself noted that their knowledge on open access was minimal prior to completing the practicum. Thus, having a library and information studies student is not necessarily a prerequisite for creating SC reports. In fact, using full-time or part-time staff may be more suitable to long-term sustainability than a one-time practicum student. Libraries could take advantage of any slow periods for staff (e.g., slow desk shifts) to assign work on a project like the SC reports. Creating and updating SC reports could be a good backup project for staff or student workers, depending on the institution and its priorities.

\section{CONCLUSIONS}

Creating scholarly communications reports for liaison librarians is not a panacea for all the challenges in changing the liaison librarian model. However, the reports can be part of a larger upskilling agenda alongside SC training and resource toolkits. This pilot project provided an additional method of integrating scholarly communications into liaison librarian roles and overcoming one of the common challenges: lack of time. These reports can assist liaison librarians with the first major obstacle in developing SC competencies: learning the research nature and culture of their department(s). SC reports have the potential to increase liaison librarians' confidence in exploring SC issues with faculty members and reduce anxiety about their own SC knowledge. Libraries could explore other staffing scenarios to make the creation and updating of these reports more sustainable in the long term. 


\section{REFERENCES}

Auckland, M. (2012). Re-Skilling for research: An investigation into the role and skills of subject and liaison librarians required to effectively support the evolving information needs of researchers. Retrieved from https://www.rluk.ac.uk/wp-content/uploads/2014/02/RLUK-Re-skilling.pdf

Bailey Jr, C. W. (2005). The role of reference librarians in institutional repositories. Reference services review, 33(3), 259-267. https://doi.org/10.1108/00907320510611294

Bakkalbasi, N., Rockenbach, B., Tancheva, K., \& Vine, R. (2016). ARL Library Liaison Institute: What we learned about needs and opportunities for reskilling. College \& Research Libraries News, 77(3), 118-121. https://doi.org/10.5860/crln.77.3.9456

Beaubien, S., Masselink, L., \& Tyron, J. (2009). Recasting the role of comprehensive university libraries: Starting points for educating librarians on the issues of scholarly communication and institutional repositories. In Proceedings from the Fourteenth National Conference of the Association of College and Research Libraries. Retrieved from http://www.ala.org/acrl/sites/ala.org.acrl/files/content/conferences /confsandpreconfs/national/seattle/papers/95.pdf

Bonn, M. (2014). Tooling up: Scholarly communication education and training. College \& Research Libraries News, 75(3), 132-135. https://doi.org/10.5860/crln.75.3.9087

Bresnahan, M. M., \& Johnson, A. M. (2013). Assessing scholarly communication and research data training needs. Reference Services Review, 41(3), 413-433. https://doi.org/10.1108/RSR-01-2013-0003

Bruns, T., Brantley, S., \& Duffin, K. (2015). Scholarly communication coaching. In B. Eden (Ed.), Partnerships and new roles in the 21st-century academic library: Collaborating, embedding, and crosstraining for the future (pp. 9-29). Lanham, MD: Rowman \& Littlefield.

Burpee, K., \& Fernandez, L. (2014). Scholarly communication at Canadian research libraries: Conversations with librarians. Journal of Librarianship and Scholarly Communication, 2(2), eP1121. https:// doi.org/10.7710/2162-3309.1121

Canadian Institutes of Health Research, Natural Sciences and Engineering Research Council of Canada, Social Sciences and Humanities Research Council. (2018). Tri-Council Policy Statement: Ethical Conduct for Research Involving Humans (TCPS2 2018). Retrieved from https:/ethics.gc.ca/eng/documents/tcps22018-en-interactive-final.pdf

Cohen, M. E. (2017). Learning the basics of scholarly communication: A guide for new subject liaison librarians. Codex: the Journal of the Louisiana Chapter of the ACRL, 4(3), 6-38. Retrieved from http:// journal.acrlla.org/index.php/codex/article/view/129

Finlay, C., Tsou, A., \& Sugimoto, C. (2015). Scholarly communication as a core competency: Prevalence, activities, and concepts of scholarly communication librarianship as shown through job advertisements. Journal of Librarianship and Scholarly Communication, 3(1), eP1236. https://doi.org/10.7710/2162-3309.1236 
Gabridge, T. (2009). The last mile: Liaison roles in curating science and engineering research data. Research Library Issues: A Bimonthly Report from ARL, CNI, and SPARC, 265(August), 15-21. https://doi.org/10.29242/rli.265.4

Hurrell, C., \& Murphy, J. E. (2019). An evidence based approach to supporting library staff scholarly communication competencies. Evidence Based Library and Information Practice, 14(2), 100-105. https://doi.org/10.18438/eblip29570

Ippoliti, C. (2017). Extreme makeover: A blueprint for redefining the role of the liaison librarian in the academic library. International Information \& Library Review, 49(4), 304-309. https://doi.org/10.1080/10572317.2017.1383743

Jaguszewski, J.M., \& Williams, K. (2013). New roles for new times: Transforming liaison roles in research libraries. Retrieved from http://www.arl.org/component/content/article/6/2893

Jenkins, B., Breakstone, E., \& Hixson, C. (2005). Content in, content out: The dual roles of the reference librarian in institutional repositories. Reference Services Review, 33(3), 312-324.

https://doi.org/10.1108/00907320510611348

Kenney, A. R. (2014). Leveraging the liaison model: From defining 21st century research libraries to implementing 21st century research universities. Ithaka $S+R$. https://doi.org/10.18665/sr.24807

Kirchner, J. (2009, August). Scholarly communications: planning for the integration of liaison librarian roles. Research Library Issues: A Bimonthly Report from ARL, CNI, and SPARC, 265, 22-28. https://doi.org/10.29242/rli.265.5

Klain-Gabbay, L., \& Shoham, S. (2016). Scholarly communication and academic librarians. Library \& Information Science Research, 38(2), 170-179. https://doi.org/10.1016/j.lisr.2016.04.004

Malenfant, K. J. (2010). Leading change in the system of scholarly communication: A case study of engaging liaison librarians for outreach to faculty. College \& Research Libraries, 71(1), 63-76. https://doi.org/10.5860/crl.71.1.63

Malone, T., \& Burke, S. (2016). Academic librarians' knowledge of bibliometrics and altmetrics. Evidence Based Library and Information Practice, 11(3), 34-49. https://doi.org/10.18438/B85G9I

Mears, K., \& Bandy, S. L. (2017). Investigating the need for scholarly communications positions in Association of Academic Health Sciences Libraries member institutions. Journal of the Medical Library Association : JMLA, 105(2), 145-149. https://doi.org/10.5195/jmla.2017.208

Miller, R., \& Pressley, L. (2015). Evolution of library liaisons (SPEC Kit 349). Washington, DC: Association of Research Libraries. https://doi.org/10.29242/spec.349

Mullen, L. B. (2011). Open access and the practice of academic librarianship: Strategies and considerations for "front line" librarians. In 2011 IATUL Annual Conference Proceedings. Retrieved from https://docs.lib .purdue.edu/iatul/2011/papers/34/ 
Phillips, H., Carr, R., \& Teal, J. (2005). Leading roles for reference librarians in institutional repositories: One library's experience. Reference Services Review, 33(3), 301-311. https://doi.org/10.1108/00907320510611339

Rodwell, J., \& Fairbairn, L. (2008). Dangerous liaisons? Defining the faculty liaison librarian service model, its effectiveness and sustainability. Library Management, 29(1/2), 116-124.

https://doi.org/10.1108/01435120810844694

Rodriguez, J. E. (2015). Scholarly communications competencies: Open access training for librarians. New Library World, 116(7/8), 397-405. https://doi.org/10.1108/NLW-12-2014-0140

Sewell, C., \& Kingsley, D. (2017). Developing the 21st century academic librarian: The research support ambassador programme. New Review of Academic Librarianship, 23(2-3), 148-158.

https://doi.org/10.1080/13614533.2017.1323766

Tierney, B., \& Kuyper-Rushing, L. (2016). A tale of two liaison programs: University of Central Florida Libraries and Louisiana State University Libraries partnering for subject librarian excellence. Presentation given at the Charleston Conference, Charleston, SC. https://doi.org/10.5703/1288284316476

Turtle, E., \& Courtois, M. (2007). Scholarly communication: science librarians as advocates for change. Issues in Science \& Technology Librarianship, 51(Summer 2007). https://doi.org/10.5062/F4319SVH

Van Orsdel, L. (2007). Faculty activism in scholarly communication: Opportunity assessment instrument. Document created for the ARL/ACRL Institute on Scholarly Communications. Retrieved from https://www. arl.org/wp-content/uploads/2007/11/scprog-fac-activism-assessment.pdf

Vine, R. (2018). Realigning liaison with university priorities: Observations from ARL Liaison Institutes 2015-18. College \& Research Libraries News, 79(8), 420-423; 458. https://doi.org/10.5860/crln.79.8.420

Walters, T. O. (2007). Reinventing the library: How repositories are causing librarians to rethink their professional roles. portal: Libraries and the Academy, 7(2), 213-225.

Wirth, A. A., \& Chadwell, F. A. (2010). Rights Well: An authors' rights workshop for librarians. portal: Libraries and the Academy, 10(3), 337-354. https://doi.org/10.1353/pla.0.0105 


\section{APPENDIX A \\ Methodology for Creating the Scholarly Communications Reports}

\section{Locating Faculty Publications Using Scopus and Web of Science}

\section{Scopus}

To search in Scopus, the student used the search query for affiliated organization and searched "McGill University" found in the field code section on the right side of the page. The student then combined the University name with the department name in parentheses and filtered for results in the last ten years.

The student selected all the articles and exported the relevant data as a CSV file to Microsoft Excel. The student then cleaned up the spreadsheet so that only the following information was on the document:

Author; Title; Source title; Year; Authors with affiliations

There was a column for access type, but often journals that Scopus listed as "Open Access" were in fact hybrid journals, so this was not a reliable source of information for access type.

\section{Web of Science}

For Web of Science, in the advanced search, the student clicked on the index for "Organization-Enhanced." Upon searching "McGill University," the student chose the first result and clicked "add" to the advanced search. Running this search showed McGill University, which the student selected. This gave a list of all the articles from McGill University researchers in the database. Scrolling down this page, on the left side of the page, there is an option to narrow by "Web of Science Categories." On this page there is an option for all the different departments at McGill University, so the relevant departments were selected.

The student then narrowed their search to the last ten years of publications, and, if necessary, narrowed the results by document type so that only articles appeared, not book chapters, meeting abstracts, or other unrelated documents.

The student exported the data by clicking "Create Citation Report" and "Save to Excel File." Note that Web of Science can only export five hundred records at a time. 


\section{Combining Data}

The student combined the results from Scopus and Web of Science through copy and paste, and then removed duplicates using the "Data" tab of Excel, then the "Remove Duplicates" button, and then remove based on duplicates in the article title column.

\section{Identifying and Researching Top Journals}

The student sorted the data on "Journal title" and identified the top journals by locating instances of three or more publications from McGill University professors in that department in that particular journal. The number of journals this resulted in varied by discipline. Once the student identified the top journals, they looked for information on each of those journals. This was a three-step process:

1. First, they consulted SHERPA/RoMEO to find copyright and licensing information for each journal, as well as embargo length if applicable. The student added this information to new columns on the Excel spreadsheet entitled "Policies" and "Embargo length."

2. Next, the student verified if the journal was Gold OA via the Directory of Open Access Journals and added this information in another new column, "Access type."

3. Finally, the student visited the website for each journal. These websites provided information on the publisher of the journal, as well as if there was a hybrid option; if so this information was added to the "Access type" column. If there was a paid open access option in a traditionally closed journal, the Article Processing Charge (APC) was added to the spreadsheet as well.

In order to see the full number of open access articles published (not just those in gold open access journals), the student looked at articles in hybrid journals that faculty published with an open access option. To do this, the student completed the work off-campus in order to see which hybrid journal articles were open. The student searched the title of the article in Google Scholar to see if there was open access to the document from that journal publisher's website. Another final column was added for "Was the article published OA?"

At this point the spreadsheet contained the following columns:

Authors; Article title; Journal title; Publisher; Year; Policies; Access type; Embargo length; APC; Was the article published OA" 


\section{Identifying Cross-Institutional Collaboration}

One liaison librarian requested information on collaboration of McGill University researchers with other institutions. Web of Science lists the affiliations of co-authors, but Scopus does not, so that data was incomplete. Instead, the student searched the database SciVal using this strategy:

Selected “Collaboration,” Filtered on subject 'Plant Science,' Years 2015-2017

SciVal does not show the exact collaborations of the articles themselves, but it gave the liaison librarian an idea of which institutions the department is collaborating with overall. 